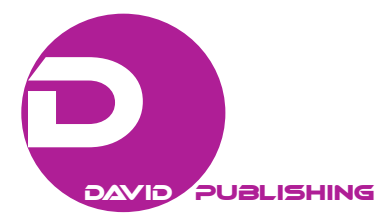

\title{
Sanur Area Development Strategy Towards Green Tourism Destination
}

\author{
I Made Sudjana \\ International Bali Institute of Tourism, Bali, Indonesia \\ I Komang Gde Bendesa, Agung Suryawan Wiranatha \\ Doctoral Program in Tourism, and Centre of Excellence in Tourism, Udayana University, Bali, Indonesia
}

\begin{abstract}
The landscape and the uniqueness of culture is the principal capital of Bali's tourism industry. The government shows its seriousness by setting the concept of tourism development in Bali as cultural tourism. Sanur is a region in Bali that relies on cultural tourism as a significant magnet in attracting tourists. However, the increasing number of tourists causes negative impacts, such as environmental damage. Applying the right tourism development strategy can help prevent environmental damage. This conceptual study attempts to identify environmental problems in Sanur area based on observation, interviews, focus group discussion, and documentation. This study used a descriptive-qualitative analytical method to formulate a strategy using the concept of 4A: attractions, amenities, accessibilities, and ancillary services that can be approached to develop Sanur into a green tourism destination. Responsible green tourism programs and plans include those that minimize the negative aspects of conventional tourism on the environment and enhance the cultural integrity of local people.
\end{abstract}

Keywords: strategy, research, tourism, development, community

\section{Introduction}

The landscape and the uniqueness of culture is the principal capital of Bali's tourism industry. The government shows its seriousness by setting the concept of tourism development in Bali as cultural tourism. Sanur is one of the tourist areas in Bali that developed steadily in more than half a century, since the early pioneering in the 1950s until now. This development is marked by the increase of tourism facilities, such as hotels and restaurants and the increasing number of tourist visits from time to time. Sanur area in South Denpasar is a tourist area that relies on cultural and maritime tourism. Sanur is famous for the beauty of its rising sun, white sand, sea views, landscape, and underwater nature. Tour events, such as Sanur Village Festival, Kite Festival, food bazaar, music and art performance, Bali Culinary Challenge, and sports tourism also mark the Sanur area as a dynamically evolving destination.

Historically, the Sanur area developed as a tourism destination that originated from the fishing village with

I Made Sudjana, SE., MM., CHT., CHA., International Bali Institute of Tourism, Bali, Indonesia.

I Komang Gde Bendesa, prof., Dr., M.A.D.E., Doctoral Program in Tourism, and Centre of Excellence in Tourism, Udayana University, Bali, Indonesia.

Agung Suryawan Wiranatha, Dr. Ir., M.Sc., Doctoral Program in Tourism, and Centre of Excellence in Tourism, Udayana University, Bali, Indonesia.

Correspondence concerning this article should be addressed to I Made Sudjana, International Bali Institute of Tourism, Jl. Tari Kecak no. 12, Gatot Subroto Timur, Denpasar, Bali 80239, Indonesia. Email: ketuastpbi@gmail.com. 
a thick marine culture which is still maintained until now. Tourism development in this region has been able to realize a destination in tune with the social and cultural values of society, and human resource capacity. The development process also puts the involvement and participation of the community in a strategic position. Often contrasted with the lively and bustling Kuta, Sanur is better known as a tourist destination that is calm and thick with a rural atmosphere with all-round facilities. In line with the dynamics of its development, it recently began to emerge several problems in Sanur. The growth of more tourism facilities is making this tourist area more crowded and less comfortable. Gautama and Sunarta (2011) in their research found that there are threats of environmental damage, such as theft of corals, overfishing, environmental pollution as well as the changes that occur due to marine tourism activities themselves. Environmental damage can be prevented by applying the right tourism development strategy. This study aims to examine the approachof tourism development in Sanur area towards green tourism destination.

\section{Literature Review}

The study by Suartika (2015) examined the conflicting interests in the use of coastal zones in Sanur area. This article focuses on the dominating influence of tourism on Sanur's development and its overarching concentration on the economic gain over social benefit. As a result, this policy has generated social conflicts, from society as a whole and local culture. The research discusses two fundamental issues, where Sanur coastal area is viewed predominantly as the public realm, and not as a capital to be exploited. First, it examines land use typologies generated by various interests. Second, how economically driven land development has both obscured and degraded environmental, social, cultural, and state interests. In the case of coastal development in Bali, discussion over these two aspects is fundamental. In contrast to other societies, the Balinese people regard the beach as a ritually important site. Symbolically, a beach is a place for disposal of waste as well as purification. If Sanur coastal area is to comply with sustainable development principles, it should conserve locally rooted traditions, economic interests, and the environment.

Green tourism is a component of sustainable tourism that is defined as a travel activity to achieve sustainability by conserving natural resources, preserving culture, and contributing to economic sectors (Graci $\&$ Dodds, 2008). Green tourism such as tourist villages, agro tourism, green guest houses, green hotels, and nature tourism is the ideal model for sustainable tourism to a new economic order (Dowling \& Fennell, 2010). As a form of alternative tourism, green tourism has a focus on capacity considerations, education, environmental conservation and local development, and local specialties. A destination deserves to be called green tourism if it has four main dimensions, namely the nature base, conservation support, sustainability, and environmental education (Weaver, 2012).

Sanur has the potential to become one of the bicycle tourist attractions as stated by Wirawan (2016). Bicycle tourism is an implementation of sustainable tourism development through the transportation aspect because it can reduce the pollution caused by the vehicle. This research was carried out by identifying potential based on the tourism components of 4A: attractions, accessibility, amenities, and ancillary services, available at Sanur are related to the development of cycling tourism. The research concludes that cycling tour has been developed in Sanur and has the potential to support the sustainability of the destination.

\section{Methodology}

The research was conducted in Sanur area in January 2018. The Sanur area is made up of three villages, 
Sanur Village, Sanur Kauh Village, and Sanur Kaja Village. The scope of this study discusses the strategy or approach needed to develop Sanur area as a green tourism destination. The research attempt to identify environmental problems based on the collected data. The object of research was then analyzed using a descriptive-qualitative analytical method to formulate the strategy. The process of data collection can be detailed as follows:

1. The observation method is used by observing the activities of travelers, locals' livelihood, and cultural and natural attractions of Sanur area. The observation is assisted by documentation, such as photos.

2. Interviews and Focus Group Discussion were conducted to obtain information related to the issues discussed and supported by taking notes of the conversation. The informants are tourism stakeholders in Sanur area: 1) the village head of Sanur District, Sanur Kaja Village, and Sanur Kauh Village. 2) the owner of Griya Santrian hotel, 3) the owner of Ena Dive Center \& Marine Adventures, 4) Tri Hita Karana Newspaper.

3. Documentation study from written documents, such as the history and profiles of Sanur area, as well as a list of detailed attractions and amenities.

\section{Results}

\section{Sanur Area Profile}

Sanur is a tourist destination located on the southern island of Bali, exactly east of the city of Denpasar. As a tourist destination, Sanur has grown since the establishment of the Bali Beach hotel by President Soekarno in 1963. The main attraction besides the culture is the beautiful natural panorama; the white sandy beach is in high demand by tourists. Sanur is known by the nickname "morning of the world from Bali", because of the beauty of morning atmosphere on the white sand beach and ramps, stretching as far as $9 \mathrm{~km}$ at the end of the eastern island of Bali (Disparda, 2015). Various facilities in the Sanur area can increase the number of tourists visiting Sanur. Based on statistical data from Denpasar Tourism Department, the number of domestic and foreign tourists who stay in Sanur from 2012-2016 increased every year, from 357,772 people in 2012 and as much as to 592,086 people in 2016, an increase of $14 \%$ from 2015.

Sanur is one of Bali's three tourism destinations in the priority of tourism development within the National Tourism Strategic Area (KSPN) together with Kuta and Nusa Dua. Based on the geographical and administrative coverage of the regional zoning, the Sanur National Tourism Strategic Area is divided into five villages, namely Sanur Kaja Village, Sanur Kauh Village, Sanur Village, Serangan District, and Kesiman Petilan Village. However within the scope of this study, it only examines the development of tourism in the village of Sanur Kaja, Sanur Kauh, and Sanur Village.

\section{Attractions}

Sanur area is famous for the beauty of its rising sun, white sand, sea views, landscape, and underwater nature. Beaches in Sanur have essential value for the sustainability of various social activities in the Balinese religion and culture. The beaches are used by the Balinese for religious activities especially for Hindu rituals, which attract tourists as a form of cultural tourism. Also present is Le Majeur Art Museum, which holds high historical and artistic value. It is named after Le Majeur, an artist from Belgium who fell in love with a local named Ni Polok, thus decided to remain in Sanur for the rest of his life.

The natural resources of Sanur Beach are utilized as a means to conduct marine tourism activities. There are four base activities in the marine tourism Sanur beach commonly done on the Sanur, namely: recreational 
water tourism activities, water sports tours, and diving and cruise activities. Because it has relatively calm waves, unlike Kuta, people cannot surf in Sanur. However, there are many diving or snorkeling sites. Due to its benign condition, this diving location can be used by divers from all skill levels. Diving activities in Sanur is now increasingly enjoyed with the proven package of scuba diving and snorkeling that is often marketed by marine tour companies in Sanur.

At this destination, tourists can also carry out sports activities such as golf, bowling and cycling. Golf and bowling facilities are available in the Grand Bali Beach Hotel environment at Sector Golf. Cycling activity is done on the designated path around the beach, village residents and paddy fields. Tourists can also watch Balinese art performances, often displayed by the hotel and restaurant.

In addition to these activities, the people of Sanur held various events as an effort to revitalize tourism potential in Sanur, such as:

(1) Kite Festival. The Kite Festival is a tradition as a form of the community celebrating over the harvest season. Therefore, the people of Sanur always fly kites alongside the beaches. The Kite Festival is held per the wind season which is around July-August each year and dubbed "Sanur International Kite Festival" (SIKF).

(2) Sanur Village Cycling Tour. This activity is pretty much in demand by the tourists, to be able to get to know Sanur more closely. The beach located in the Sanur area has a particular path for cycling that is very easy to reach from various locations. The tourists can enjoy the beauty and freshness of the beach and see the activities of fishers and residents with a bike ride.

(3) Bali Culinary Challenge. Bali has various local delicacies that can be enjoyed by tourists. Bali Culinary Challenge is a cooking competition using multiple ingredients, such as fish, meat, vegetables, fruits, and basa genep (various Balinese spices).

(4) Sanur Village Festival. This five-day festival is held annually, aims to facilitate and develop the Sanur community's creativity and achieve creativity and tourism synergy. Visitors can look forward to the fun and cultural programs held during the festival. Culinary experience can be found in the food bazaar, all at very moderate prices. Visitors can enjoy the night festival with traditional cultural performances, from Bali and Indonesia, collaborating with the modern music genre.

\section{Amenities}

The facilities at Sanur consisted of accommodation facilities, culinary, and art stalls along the coast. Tourists can also shop trinkets, clothes, artworks, and paintings. Public facilities, such as public bathrooms, garbage bins, information boards, and parking lots, are still considered inadequate. Common public facilities, such as public bathrooms, locker rooms and showers, trays, parking lots, communication devices, and information boards, are also available.

Until 2017, facilities in Sanur include tourism accommodation facilities, such as 26 star hotels and 85 non-star hotels (BPS Denpasar, 2017). The hotels are located close to residential residents, which makes Sanur an accessible tourism area, in contrast to Nusa Dua, which is a closed tourism area. Sanur is also often used as a meeting, incentive, convention, and exhibition (MICE) destination, held in other hotels and venues spread across the Sanur area.

The quality of hotels and accommodation in Sanur is a market for upper-middle-class tourists. Hotel and accommodation rates depend on the facilities and location owned by the hotel, the closer to the beach; then hotel prices will also be higher. Most of the hotels in Sanur are located on the beach, on the east side of Ngurah 
Rai ByPass road. The western part is dominated by villa-type accommodation for tourists with longer staying time.

\section{Accessibilities}

A place is more likely to get visitors based on facilities, such as road infrastructure, distance to the airport, and transportation availability. Which for Sanur is very good, as the road is easily accessible, close to the airport and the city center. Access to Sanur Beach is currently very adequate after the government builds pedestrian paths. However, as the number of tourists grew, the road leading to the beach is prone to congestion because of the lack of parking areas. People began using part of the public highway as parking areas, which makes the road challenging to access, such as the road leading to Inna Grand Bali Beach hotel.

The accessibility problem also appeared on the beach. It is densely populated by boats, operational and semi-abandoned, moored alongside the coast untidily, which may block the mooring of other boats. The transport systems of these boats also result in visual pollution in the landscape and environmental damage due to engine fuel pollution, seagrass destruction by ship propellers, and damage to coral reefs caused by boat anchors.

\section{Ancillary Services}

Sanur area has a structured government institution. The coordination of duties, authority, and responsibilities between sectors of government starts from the village, district, province, to the central level. Also, several non-governmental institutions observe the coast of Sanur and participate in the general development of Sanur Area, including tourism.

One such organization is The Sanur Development Foundation (Yayasan Pembangunan Sanur or YPS), established in 1965 by about 22 people who are concerned with the development of Sanur. At that time, Sanur is listed as one of the most rapidly growing tourist areas in Bali. The development of tourism often causes friction in the middle of society, both economic and socio-cultural (a clash between the pattern of modern life with the traditional model). This fact prompted the founders of YPS to provide an organization that could bridge the interests of citizens with the tourism industry players and all parties who have interests in Sanur. YPS commonly tries to solve various problems such as security issues, environmental hygiene, cultural preservation, and community economic empowerment.

\section{Discussion}

The United Nations Committee on Environment and Development published the "Brundtland Report" in 1987 and formally defined sustainable development, which provided ideas for the concept of green tourism. Since then, the idea of green development has been gradually integrated into many aspects of the sustainable development of tourism. These aspects include the measure of tourism eco-efficiency, the social impact of tourism, relationships between tourism economic benefits and environmental costs, green tourism products for the hotel and scenic spots (Tang et al., 2017).

In broad concepts, green tourism is a mode of tourism economic development that advocates recycling. Green tourism in narrow concepts is a kind of tourist activity that pays attention to resources and protects ecology. Carrying the concept of nature and marine tourism, Sanur has a chance to develop into a green tourism destination. To gain a suitable tourism strategy, it is crucial to identify the problems which threaten the sustainability of the environmental ecosystem in Sanur. The data collected from observation, documentation, 
interviews, and FGDare used as the means to identify these problems.

The research found there are some problems in the attractions, amenities, accessibilities, and ancillary services (4A) of Sanur in terms of sustainability. By identifying these problems, a strategy can be formulated to develop Sanur into a green tourism destination.

Marine and water tourism is the main attraction of Sanur. The beach as Sanur's most important asset needs to be protected from undergoing degradation from the threats of environmentally unfriendly fishing methods, solid and liquid waste from the tourism industry. Incorrect handling of industrial wastes may threaten the ecosystem of Sanur beaches. Creating a sanitation system for tourism and human activities, as well as tackling solid and liquid waste generated from upland areas will help prevent damages on one ecosystem spread into the others.

Promoting eco-friendly tourist attractions requires a joint effort of all parties, both government and private sectors. These efforts can range to the revised regulation of waste and trash disposal, and assign a designated area for water tourism to avoid damaging coral reefs. Diving areas should be protected from other activities because coral reefs are the most vulnerable to ecosystem changes.

While amenities, such as hotels, art shops, bars, and restaurants are abundant, facilities that receive less attention are public facilities. It is not easy to find a public toilet, and the ones that are available are not maintained well and need improvements, such as ease of access for disabled people. While businesses are proliferating, various types of accommodation businesses, restaurants, bars, art shops increasingly filled the beach area. Some of them are not organized well, opening stalls that lacked does not up to standards, and this creates a problem of visual pollution. Traders, booths, and street vendors on Sanur area need to be certified and allocated to a dedicated place.

In the absence of information and regulations, visitors often do activities that threaten their own life or activities that especially harmful to the coastal area of Sanur. Littering has become a problem, even though there are already trash cans placed strategically alongside the beaches. Based on the interview with the head of the service and community section of Sanur Kauh Village Office, Sanur has already implemented self-management of waste in Depo Palesari (temporary landfill). The landfill sorts between organic and inorganic solid waste. Organic waste from then processed into compost, while inorganic waste is taken to the final landfill in Suwung area.

Sanur area itself is easily accessible by tourists, but the parking space often exceeds the capacity. The use of vehicles causes growing concerns about air pollution due to vehicle gas disposal. The boat's anchor also threatens to damage the coral reef in Sanur. To realize sustainable and green tourism destination, one way to overcome this problem is to apply the concept of carrying capacity taken from the theories of sustainable use of the natural environment. This includes:

(a) Arranging boat moorings so as not to interfere with other activities and prevent environmental damage;

(b) Determine the ideal number of boats so as not to exceed the capacity of Sanur beach;

(c) Determining tolerable parking capacity;

(d) Accessibility management may not be specified by either party; the government is to authorize the regulation and enforcement of the rules.

Advocating the use of pollution-free transportation and activities, such as bicycle tours can also contribute to training green consumers. Sanur has already started implementing bicycle-only track to accommodate low-carbon transportation users. Sanur also cooperates with the bike-sharing platform Gowes. Launched in 
Sanur Village Festival 2018, this provides at least 100 bicycles in 12 location spots along Sanur beach and Danau Tamblingan Street. Customers could easily download the Gowes app and top up the credit to use the bike. The regulations of traffic and encouraging walking tours can promote physical and mental health and further develop the green lifestyle of visitors at the same time.

Tourism in Sanur area is managed by the government and private sector. Private NGO such as Yayasan Pengembangan Sanur (YPS) was established to ensure the locals can participate and get profit off tourism in Sanur. One such activity is Sanur Village Festival (SVF); YPS founded the annual community event since 2006 to great success. The event is a combination of several large-scale activities involving food festival, creative economy exhibitions, various contests and competitions, art and cultural attractions, music as well as multiple types of environmentally-friendly activities. Aside from promoting the destination, this event also supports culture preservations, along with community economy and welfare.

\section{Conclusions}

Sanur consists of various social layers ecosystems that are interconnected. A small change, either natural or unnatural, will change the state of the area. By identifying potential based on the tourism components of $4 \mathrm{~A}$ of attractions, accessibility, amenities, and ancillary services, Sanur has excellent potential to be developed into a green tourism destination. Government and other stakeholders should provide and fix public facilities, such as public toilets, garbage cans, parking area, information, and regulatory boards.

Maintaining Sanur Beach's sustainability and cleanliness is crucial to create healthy coastal environmental and avoiding damage to the ecosystem, such as conducting ecological rescue activities, renewing and caring for damaged ecosystems, as well as the need for coastal structuring for street vendors. Tourism stakeholders in Sanur should make the scientific planning of green tourism to guide rational exploitation of the tourism industry and enterprises. Such plans are essential to protect resources, environment, cultural heritage, sustainable development of social economy, and tourists' satisfaction.

\section{References}

BPS Kota Denpasar. (2017). Denpasar Selatan Dalam Angka 2017. Badan Pusat Statistik.

Damayanti, I. A. K. W., Wijaya, I. N., \& Kanca, I. N. K. (2017). Strategi pengembangan Pulau Nusa Penida sebagai kawasan pariwisata yang berkelanjutan. Soshum: Jurnal Sosial dan Humaniora, 5(2), 136.

Dinas Pariwisata Pemerintah Provinsi Bali. (2015). Direktori 2015. Disparda Bali.

Dowling, R. K., \& Fennell, D. A. (2010). The Context of Tourism Policy and Planning. CAB International Journal, 1-20.

Gautama, I. G. A. G. O., \& Sunarta, I. (2011). Evaluasi perkembangan wisata bahari di Pantai Sanur (Master Programme, Udayana University, Denpasar).

Graci, S., \& Dodds, R. (2008). "Why Go Green? The Business Case for Environmental Commitment in the Canadian Hotel Industry”. Anatolia: An International Journal of Tourism and Hospitality Research, 19(2), 250-270.

Pickel-Chevalier, S., \& Ketut, B. (2016). Towards sustainable tourism in Bali: A Western paradigm in the face of Balinese cultural uniqueness. Retrieved from https://www.researchgate.net/publication/308179509_Towards_sustainable_tourism_in_Bali_A_Western_paradigm_in_the_ face_of_Balinese_cultural_uniqueness

Putra, I. N. D. (2014). Bali: Between cultural and marine tourism. Jurnal Kajian Bali, 4(1), 15-30.

Roly, M. R., Siwar, C., Ismail, S. M., \& Salleh, N. H. M. (2015). Exploring the indicators for environmental protection in the context of green tourism. Advanced Science Letters, 21(6), 1786-1790.

Suartika, G. A. M. (2015). Sand, sea and ceremony: Conflict over the littoral public realm in Sanur, Bali. Procedia-Social and Behavioral Sciences, 179, 128-140. 
Tang, C. C., Zheng, Q. Q., Qin, N. N., Sun, Y., Wang, S. S., \& Feng, L. (2017). A review of green development in the tourism industry. Journal of Resources and Ecology, 8(5), 449-459.

Weaver, D. B. (2012). Organic, incremental and induced paths to sustainable mass tourism convergence. Tourism Management, 33(5), 1030-1037.

Wirawan, K. (2016). Wisata Sepeda Dalam Mewujudkan Pariwisata Berkelanjutan Di Sanur. Jurnal Magister Pariwisata, 2(2), $1-16$.

Zhong, L. S., \& Zeng, Y. X. (2016). Green development concept brings new topics to China's tourism industry. Tourism Tribune, $31(10), 1-3$. 